\title{
Audit Hak Kekayaan Intelektual Sebagai Bagian Pengelolaan Risiko Kerugian Bisnis Bagi Perusahaan
}

\author{
Kusnadi $^{1}$ Budi Santoso $^{2}$
}

\begin{abstract}
ABSTRAK
Penelitian bertujuan untuk mengetahui audit hak kekayaan intelektual sebagai bagian pengelolaan resiko kerugian bisnis bagi perusahaan. Aset Hak Kekayaan Intelektual (HKI) saat ini masih dipandang sebelah mata oleh sebagian besar perusahaan di Indonesia. Apabila mengingat terhadap nilai ekonomi yang dihasilkan dari aset tersebut jauh lebih menguntungkan dibandingkan dengan aset berwujud lainnya (tangible assets). Penelitian ini dilakukan dengan menggunakan metode pendekatan yuridis normatif, sehingga sumber data yang digunakan merupakan data sekunder yang diperoleh melalui studi kepustakaa. Data hasil penelitian dianalisis secara normatif kualitatif. Hasil Penelitian ditemukan bahwa konsep Audit HKI berbasis risiko dapat digunakan oleh perusahaan dengan cara mengetahui terlebih dahulu peran dan posisinya dalam perusahaan, kemudian waktu yang tepat dan ruang lingkup identifikasi pelaksanaan audit Audit HKI berbasis risiko serta tahapan-tahapan dalam pelaksanaan audit HKI berbasis risiko kerugian bisnis. Fenomena risiko muncul dari pemeliharaan dan penjagaan aset hak kekayaan intelektual yang tidak dikaji secara spesifik dan terukur.
\end{abstract}

Kata Kunci: Hak Kekayaan Intelektual, Audit HKI, Aset Perusahaan, Risiko Bisnis

\footnotetext{
${ }^{1}$ Mahasiswa Program Studi Magister Ilmu Hukum UNDIP

${ }^{2}$ Dosen Program Studi Magister Ilmu Hukum UNDIP
} 


\section{A. Latar Belakang.}

Pemerintah Indonesia melalui

UU No. 7 Tahun 1994 meratifikasi

"Agreement Establishing the World

Trade Organization" (Persetujuan

Pembentukan

Organisasi

Perdagangan Dunia dan sebagai lampirannya adalah Trade Related Aspects of Intellectual Property Rights) dan juga dengan UU No. 5 Tahun 1994 telah diratifikasi United Nations Convention on Biological Diversity (Konvensi Perserikatan Bangsa-Bangsa tentang Keanekaragaman Hayati). Dengan Keputusan Presiden No. 15 tahun 1997 tentang Ratifikasi Paris Convention for the Protection of Industry Property (Konvensi Paris).

Persetujuan TRIPs juga mengacu pada "Treaty on Intellectual Property in Respect of Integrated Circuits" (Washington Treaty). Selain itu pemerintah Indonesia juga meratifikasi "Berne Convention for the Protection of Artistic and Literary Works" (Konvensi Berne tentang Perlindungan Karya Seni dan Sastra) melalui Keputusan Presiden No. 18 tahun 1997 dan "World Intellectual Property Organization Copyrights
Treaty" (Perjanjian Hak Cipta WIPO) melalui Keputusan Presiden No. 19 Tahun 1997.

Konsekuensi dari ratifikasi tersebut, pemerintah Indonesia berkewajiban memberikan perlindungan terhadap Hak atas Kekayaan Intelektual tersebut. pada mulanya yang termasuk HKI hanyalah Hak Paten, Hak Merek dan Hak Cipta namun perkembangan akhir-akhir ini termasuk juga Varietas Tanaman, Rahasia Dagang, Desain Industri dan Desain Tata Letak Sirkuit Terpadu. ${ }^{3}$ Dimana terdapat nilai ekonomi yang besar pada setiap HKI tersebut bila dimanfaatkan dengan baik dan benar. Kepemilikan nilai ekonomi yang ditambah dengan manfaat ekonomi yang dapat dinikmati menumbuhkan konsepsi kekayaan (property) terhadap karya-karya intelektual. Bagi dunia usaha, karya-karya itu dikatakan sebagai bentuk aset tidak berwujud (intangible assets) perusahaan. ${ }^{4}$

\footnotetext{
3 Nyoman Serikat Putra Jaya, Hukum dan Hukum Pidana diBidang Ekonomi, (Semarang: Badan Penerbit Universitas Diponegoro, 2012), hlm. 37

${ }^{4}$ http://duniakuro.wordpress.com/?s=Sejarah $+\mathrm{HAKI} \% 28$ dedikasi+peringatan+hari+H AKI+sedunia+26+April+2011\%29, diakses Rabu, 11 September 2013
} 
Pengakuan

dan

perlindungan hukum hak kekayaan intelektual sebagai aset organisasi perusahaan dapat berkontribusi pada peningkatan meraih keuntungan yang sebesar-besarnya tanpa harus dilakukannya penyimpangan hukum, atau dengan adanya pengakuan dan perlindungan hukum tersebut dapat pula menjadikan aset perusahaan tersebut berada dalam posisi aman dan jauh dari risiko bisnis yang berujung pada risiko kerugian.

\section{Bagan 1}

\section{Jenis-Jenis Aset Tidak Berwujud}

(Intangible Assets)
Auditing: A Raod to Riches,

Hournal of Research and

Pratice in Information

Technology, Vol. 35,No.3, August 2003

Aset Kekayaan Intelektual sering menjadi salah satu aset yang paling berharga yang dimiliki oleh sebuah perusahaan. Sebagai contoh baru-baru ini perusahaan Apple telah memenangkan sengketa pelanggaran HKI di Peradilan terhadap perusahaan Samsung dengan lebih

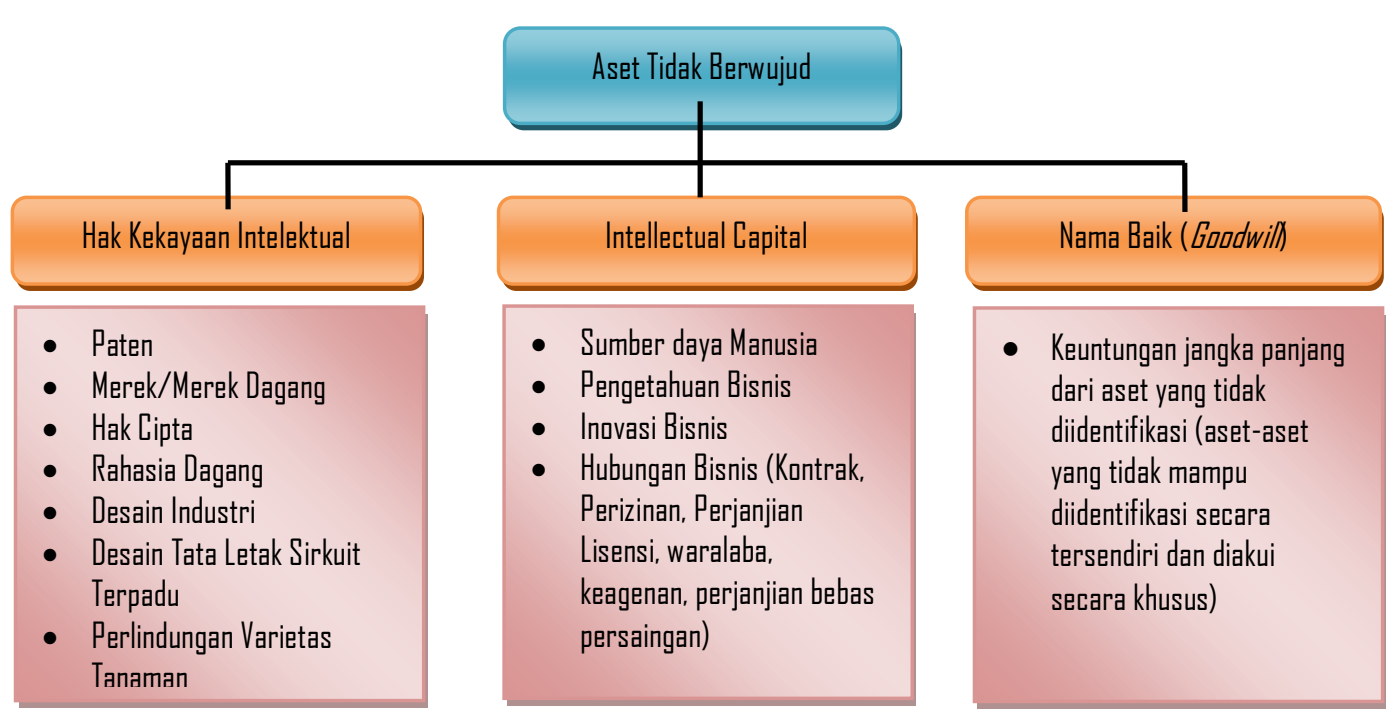

Sumber: dikutip dari Sharyn Ch'ang \& Marina Yastreboff, Intellectual Property dari \$ 1 milyar atas pelanggaran yang disengaja pada desain Apple dan penggunaan patennya. Selain itu 
perusahaan Coca Cola yang mempunyai rahasia dagang yang berharga dan terkenal serta dijaga ketat untuk kepentingan bisnis perusahaannya. Coca Cola telah menolak untuk mengungkapkan rahasia dagangnya yang lebih dari puluhan tahun walaupun atas dua kali perintah pengadilan.

Begitu pula Merek dagang Google diperkirakan bernilai $27 \%$ dari total nilai perusahaan sekitar \$ 44 miliar. Nama domain juga bisa bernilai beberapa juta dolar seperti 'toys.com' dilelang di $\$ 5,1$ juta dan 'sex.com' dijual seharga \$ 11 juta. Meskipun fenomena ini adalah keadaan ekstrem terhadap sebuah bisnis, namun saat ini memang banyak bisnis menghasilkan keuntungan yang signifikan dari kepemilikan kekayaan intelektual mereka ${ }^{5}$

Perusahaan sebagai institusi bisnis seharusnya jeli dan waspada terhadap pengelolaan inventarisasi aset yang dicatatkan dan dituliskan dalam pembukuan perusahaan yang

5 Stacey \& Halpern, etc, Protecting your Company's Intellectual Property Through an IP Audit: a Guide for Small to Mid-Sized Businessess,(USA: Execsense, Inc. 2012) pages.iii bertujuan mendeteksi risiko kerugian yang lebih besar dikemudian hari.

Berkaitan dengan ketertiban administrasi dan pembukuan bagi perusahaan telah diatur memiliki catatan kekayaannya, baik berupa aset berwujud maupun aset tidak berwujud, dimana hal tersebut saat ini telah diatur secara khusus dalam pasal 6 KUHD, yaitu:

"Setiap orang yang menyelenggarakan suatu perusahaan, iapun tentang keadaan kekayaannya dan tentang segala sesuatu berkenaan dengan perusahaan itu diwajibkan, sesuai dengan kebutuhan perusahaan, membuat catatan dengan cara demikian, sehingga sewaktuwaktu dari catatan itu dapat diketahui segala hak dan kewajibannya."

Pembukuan atau pencatatan aset perusahaan saat ini telah diatur secara khusus didalam UU No. 8 tahun 1997 tentang Dokumen Perusahaan. Sebagaimana disebutkan dalam pasal 8 ayat (1) jo. Pasal 5 UU No. 8 tahun 1997, yaitu: "Setiap perusahaan wajib membuat catatan 
sebagaimana dimaksud dalam pasal

5 sesuai dengan kebutuhan

perusahaan." Pasal 5 menjelaskan:

"Catatan terdiri dari neraca

tahunan, perhitungan laba rugi

tahunan, rekening, jurnal transaksi

harian, atau setiap tulisan yang

berisi keterangan mengenai hak dan

kewajiban serta hal-hal lain yang

berkaitan dengan kegiatan usaha

suatu perusahaan".

Pembukuan ini merupakan

pencatatan-pencatatan mengenai

"keadaan kekayaannya", pencatatan-

pencatatan mana harus diwujudkan

sedemikian rupa, sehingga dari

pencatatan itu setiap waktu dapat

diketahui hak-hak dan kewajiban-

kewajibannya, sudah barang tentu

terhadap pihak-pihak ketiga dengan

mana pengusaha selalu berhubungan

hukum (mengadakan pelbagai

perjanjian-perjanjian dan

sebagainya). ${ }^{6}$

Pengelolaan aset kekayaan

intelektual belum terkelola secara maksimal oleh sebagian besar perusahaan di Indonesia. Hal ini terbukti dari masih maraknya kasus pelanggaran dan sengketa dibidang

\footnotetext{
${ }^{6}$ R. Soekardono, Hukum Dagang Indonesia: Jilid I, cet. ke-9, (Jakarta: Dian Rakyat, 1993), hlm. 31.
}

Hak Kekayaan Intelektual di Indonesia. Sebanyak 192 kasus pelanggaran terjadi dalam periode Juli-Desember 2008. ${ }^{7} \quad 112$ kasus ditangani polisi dan 80 kasus ditangani kejaksaan.

Begitu pula dengan kasus pelanggaran HKI yang ditangani oleh Direktorat Penyidikan Direktorat Jenderal Hak Kekayaan Intelektual Kementerian Hukum dan HAM menangani 33 kasus dengan klasifikasi pelanggaran hak Cipta 2 kasus, Merek 26 kasus dan Desain Industri 5 kasus. Sedangkan melalui Tim Nasional Penanggulangan Pelanggaran Hak Kekayaan Intelektual (Timnas PPHKI) menangani 121 perkara HKI pada tahun $2011^{8}$. Sementara pada tahun 2012 Ditjen HKI menangani per bulan Mei sebanyak 44 kasus ${ }^{9}$. Belum lagi jumlah sengketa perdata HKI di Pengadilan Niaga dan Pengadilan Negeri.

\footnotetext{
7 http://life.viva.co.id/news/read/53933indonesia_masuk_daftar_hitam_as, diakses pada 11 September 2013.

8 Annual Report Laporan Tahuan 2011 Direktorat Jenderal Hak Kekayaan Intelektual Kementerian Hukum dan HAM 9 RI, (Jakarta; Ditjen HKI, 2011) hlm. 51

http://jogja.okezone.com/read/2012/07/10/6 61440/pemerintah-tangani-44-kasuspelanggaran-hki, diakses pada 10 September 2013
} 
Pelanggaran terhadap HKI tersebut dapat dikelola tingkat risiko hukumnya dengan mekanisme audit Hak Kekayaan Intelektual (HKI). Audit HKI merupakan suatu prosedur mengkaji ulang (review) terhadap kebijakan-kebijakan pengelolaan Hak Kekayaan Intelektual serta prosedur yang digunakan oleh organisasi (perusahaan) untuk mengidentifikasi, memperoleh dan melindungi Hak Kekayaan Intelektual-nya dan melindungi organisasi tersebut dari HKI orang lain. ${ }^{10}$

Penggunaan Audit HKI yang dirumuskan dalam penelitian ini adalah sebagai sebuah proses untuk mengantisipasi perusahaan dari risiko negatif akibat dari ketidaktahuan kewajiban yang harus dipenuhi perusahaan berkaitan dengan HKI pihak lain. Dengan kata lain, tujuan lain dari audit HKI ini adalah untuk memberikan semua kenyamanan dalam berusaha. ${ }^{11}$

Kegiatan audit berupa pengelolaan dan inventarisasi Hak Kekayaan Intelektual adalah bagian

10 William W Cochran, Intellectual Property Audits, Makalah tanpa tahun.

${ }_{11}$ Budi Santoso, Hukum Hak Cipta, Catatan Perkuliahan pada Magister IImu Hukum UniversitasDiponegoro Semarang, 2013 dari manajemen risiko bisnis organisasi perusahaan. Kegiatan identifikasi dan pengelolaan terhadap risiko-risiko tersebut penting karena pada dasarnya setiap hari organisasi perusahaan akan menghadapi berbagai macam risiko atas berbagai kegiatan bisnis yang dilakukan maupun akibat dari keputusan manajemen yang ambil.

Risiko merupakan ketidakpastian terhadap probabilitas terjadinya suatu peristiwa serta dampak dari peristiwa tersebut apabila benar-benar terjadi yang dapat memiliki pengaruh material terhadap pencapaian tujuan organisasi perusahaan. ${ }^{12}$

Maka permasalahan dalam penelitan ini dapat dikaji dengan batasan-batasan yang lebih jelas demi mengihindari kerancuaan atau keluasan pembahasan. Sehingga berdasarkan latar belakang di atas perlu dikaji beberapa hal, antara lain: pertama, bagaimanakah peran dan kedudukan audit Hak Kekayaan Intelektual (HKI) yang digunakan sebagai sarana untuk mengantisipasi dan/atau meminimalisir risiko

12 Ardeno Kurniawan, Audit Internal Nilai Tambah Bagi Organisasi, (Yogyakarta: BPFE- UGM, 2012) hlm. 65 
kerugian di perusahaan saat ini. Kedua, Bagaimanakah implementasi atau langkah-langkah yang diperlukan dalam audit Hak Kekayaan Intelektual yang dapat untuk mengantisipasi dan/atau meminimalisir risiko bisnis bagi Perusahaan.

\section{Metode Penelitian}

Metode pendekatan yang digunakan oleh peneliti dalam penelitian ini adalah pendekatan yuridis normatif, dengan meniti beratkan pada studi kepustakaan. Studi kepustkaan dilakukan untuk untuk mencari bahan hukum primer, sekunder dan tersier. Keseluruhan data dianalisis secara kualitatif deskriptif. Kualitatif deskriptif maksudnya adalah bahwa penulis dalam menganalisis berkeinginan untuk memberikan gambaran atau pemaparan atas subjek dan objek penelitian sebagaimana hasil penelitian yang dilakukannya ${ }^{13}$.

\section{Tinjauan Teori}

Hak kekayaan intelektual adalah hak yang timbul dari kemampuan berpikir atau olah pikir yang menghasilkan suatu produk

13 Ibid., hlm. 183 atau proses yang berguna untuk manusia. Menurut sarjana hukum kekayaan intelektual lain mendefinisikan hak kekayaan intelektual secara harfiah, Hak merupakan lembaga/pranata sosial dan hukum. Hak selalu berkaitan dengan dua aspek, yaitu aspek kepemilikian (owner) dan sesuatu yang dimiliki (something owned). Terminologi hukum menggabungnya dan menyatukannya ke dalam istilah hak (right). ${ }^{14}$

L. J. Van Aveldroon menyatakan, hak adalah hukum yang dihubungkan dengan seseorang manusia atau subjek hukum tertentu dan menjelma menjadi suatu kekuasaan dan suatu hak timbul apabila hukum mulai bergerak. ${ }^{15}$

Kekayaan (property) merupakan padanan kata kepemilikan (ownership). Maka kekayaan dapat diartikan kepemilikan atas suatu benda sebagai konsekuensi dari diberikannya hak kepada seseorang oleh hukum. sementara kata intelektual (intellectual) bermakna kecerdasan,

\footnotetext{
14 Ontoeng Soerapati, Hukum Kekayaan Intelektual dan Alih Teknologi, (Salatiga: Fakultas Hukum UKSW, 1999), hIm. 9.

${ }^{15}$ C.S.T. Kansil, Pengantar IImu Hukum dan Tata Hukum Indonesia, (Jakarta: Balai Pustaka, 1989), hlm. 119.
} 
daya pikir dan kemampuan otak yang dimiliki oleh seseorang. Maka HKI dapat diartikan sebagai kekuasaan yang diberikan oleh hukum kepada subjek hukum (manusia/badan hukum) terhadap suatu benda yang merupakan hasil dari kecerdasan intelektual manusia. ${ }^{16}$

Kekayaan atau aset berupa karya-karya yang dihasilkan dari pemikiran atau kecerdasan manusia mempunyai nilai atau manfaat ekonomi bagi kehidupan manusia sehingga dapat dianggap juga sebagai aset komersial. Karya-karya yang dilahirkan atau dihasilkan atas kemampuan intelektual manusia sudah sewajarnya diamankan dengan menumbuh-kembangkan sistem perlindungan hukum atas kekayaan tersebut yang dikenal sebagai sistem Hak Kekayaan Intelektual (HKI).

\section{Gambar}

\section{Pengertian KI \& HKI}

Menurut TRIPs (Trade Related Aspects of Intellectual Property Rights), dalam pasal 1 ayat (2) menyebutkan HKI adalah semua kategori kekayaan intelektual sebagaimana dimaksud dalam bagian 1 sampai dengan 7 Bab II Agreement TRIPs yang mencakup: a) Hak Cipta dan Hak-Hak terkait lainnya (Copyrights and Related Rights), b) Merek Dagang (Trade Marks), c) Indikasi Geografis (Geographical Indications), d) Desain Produk Industri (Industrial Designs), e) Paten (Patent), f) Desain Topografi (Lay Out) dari Rangkaian Elektronik Terpadu (Lay Out Designs (Topographies) of Integrated Circuits), g) Perlindungan terhadap informasi yang dirahasiakan (Protection of Undisclosed Information), h) Control of Anti Competitive Practices in Contractual Licences.

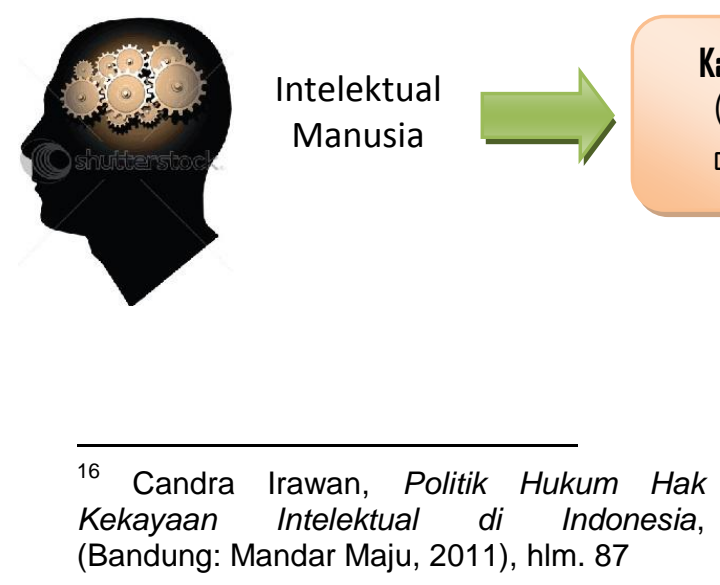

Karya Intelektual (invensi, kreasi, ciptaan, desain)
Perlindungan hukum

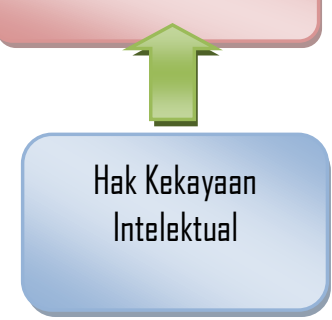


Disamping itu, sistem HKI menunjang diadakannya sistem dokumentasi yang baik atas segala bentuk kreativitas manusia sehingga kemungkinan dihasilkannya teknologi atau hasil karya lainnya yang sama dapat dihindarkan atau dicegah. Dengan dukungan dokumentasi yang baik tersebut, diharapkan masyarakat dapat memanfaatkannya dengan maksimal untuk keperluan hidupnya atau mengembangkannya lebih lanjut untuk memberikan nilai tambah yang lebih tinggi lagi. ${ }^{17}$

$$
\text { Pengakuan terhadap }
$$

perlindungan HKI secara filosofis terkait erat dengan pemikiran mazhab atau doktrin hukum alam yang menekankan pada faktor manusia dalam menggunakan akalnya untuk memecahkan masalahmasalah yang dihadapi dalam semua aspek kehidupannya.

Thomas Aquinas, seorang filsuf dari abad pertengahan (12261274) menyatakan bahwa hukum alam merupakan bagian dari hakikat kehidupan dan melalui hukum alam manusia berpartisipasi sebagai

17 Krisnani Setyowati, Efridani Lubis dkk., Hak kekayaan Intelektual dan Tantangan Implementasinya di Perguruan Tinggi, (Bogor: Kantor HKI-IPB, 2005), hlm. 2 makhluk rasional (berakal). Hukum alam adalah bagian dari hukum Tuhan. Manusia sebagai makhluk berakal menerapkan bagian dari hukum Tuhan terhadap kehidupannya sehingga ia dapat membedakan yang baik dan yang buruk. $^{18}$

Hubungannya dengan HKI, teori hukum alam dapat digunakan sebagai falsafah bahwa dengan akal yang diberikan Tuhan, manusia dapat memecahkan semua permasalahan yang dihadapi dalam kehidupannya. Manusia dapat menciptakan karyakarya intelektual mulai dari bendabenda yang paling sederhana sampai dengan invensi-invensi yang memerlukan pemecahan teknologi sesuai dengan kebutuhan.

John Lock dalam karyanya yang terkenal Two Treaties of Government, pada intinya mengemukakan bahwa manusia sejak dilahirkan telah mempunyai hak mewarisi dunia yang diberikan oleh Tuhan. Ia mengatakan bahwa: "every man has a "property" in his own "person". The labour of his

\footnotetext{
18 Justin Hughes, The Philosophy of Intellectual Property, (Washington: Georgetown Law Journal, 1988), pages 77.
} 
body, and the work of his hand, we may say, are properly his. ${ }^{19}$

Teori ini kemudian dikenal dengan apa yang disebut sebagai Labour Theory yang menurut Justin Hughes, walaupun tidak lengkap (incomplete), sangat kuat dalam memberikan landasan bagi perlindungan terhadap HKI. ${ }^{20}$

Titik tekan pada teori karya (labour theory) terletak pada aspek proses menghasilkan sesuatu dan sesuatu yang dihasilkan. Semua orang memiliki otak, namun tidak semua orang mampu mendayagunakan fungsi otaknya (intelektual) untuk menghasilkan sesuatu. Menurut teori motivasi yang dikemukan oleh David Mc Clelland, bahwa seseorang menghasilkan sesuatu karena memang memiliki motivasi untuk berprestasi. ${ }^{21}$

Kaitannya dengan HKI adalah perlunya kepada pencipta, pendesain atau inventor diberikan balas jasa atas karya yang telah dihasilkannya. Orang dapat mengambil manfaat dari karya HKI tersebut, namun juga harus

19 Justin Hughes, Op. Cit, pages. 24

${ }^{20}$ Ansori Sinungan, Op. Cit, hlm. 3

21 Adam I. Indrawijaya, Perilaku Organisasi, cetakan VI, (Jakarta: Sinar Baru Algensindo, 2000), hlm. 6 memberikan sesuatu kepada pencipta, pendesain atau inventornya. Ada semacam pertukaran yang dilakukan atau hubungan timbal balik yang saling menguntungkan. Pencipta, pendesain atau inventor akan merasa dihargai hasil karya dan jerih payahnya, sehingga termotivasi untuk semakin giat menghasilkan karya-karya baru yang bermanfaat lainnya. ${ }^{22}$

\section{B. HASIL PENELITIAN DAN PEMBAHASAN}

\section{Audit HKI Sebagai Sarana Antisipasi dan/atau}

\section{Minimalisasi Risiko Kerugian}

\section{Bisnis}

Pemahaman terhadap audit HKI karena persaingan bisnis yang semakin kompetitif dan didorong oleh inovasi yang cepat, kesadaran perusahaan mulai muncul dengan memposisikan audit kekayaan intelektual lebih dekat ke dalam bagian dari struktur perusahaan.

Secara garis besar ada tiga alternatif posisi atau kedudukan dari Internal Auditing (pihak yang melakukan auditing disebut Auditor) dalam struktur organisasi

22 Candra Irawan, Op. Cit., hlm. 50 
perusahaan $^{23}$ yaitu: organisasi perusahaan. Yaitu: 1) Internal Auditing berada di bawah Dewan Komisaris 2) Internal Auditing berada di bawah Direktur Utama 3) Internal Auditing berada di bawah Kepala Bagian Keuangan dan Divisi Hukum.

Audit HKI dapat juga dilakukan oleh para staf atau personil internal perusahaan yang bukan advokat/konsultan HKI apabila mereka memiliki pengetahuan yang mumpuni tentang HKI untuk melakukan proses auditing yang diperlukan dalam kegiatan audit kekayaan intelektual perusahaan. Biasanya personil internal perusahaan itu dapat berasal dari divisi keuangan atau divisi pemasaran atau divisi penelitian dan pengembangan teknologi dan divisi desain graphis atau engineering. Hal ini dikarenakan kompleksitasnya material-material dari kekayaan intelektual yang tidak cuma sebatas bentuk produk dari perwujudan HKI semata.

Tujuan perlindungan aset perusahaan adalah untuk menjaga

23 Manahan Nasution, Sekilas tentang Internal Auditor, makalah,( Sumatra: FE USU, 2003), hlm. 4 keamanan dan keberlangsungan kegiatan usaha, memberikan kepastian hukum, serta melindungi perusahaan dari gangguan pihak lain. Salah satu metodologi untuk melakukan perlindungan aset tersebut dilakukan melalui proses audit HKI. Secara umum, audit HKI sebagai inspeksi kekayaan intelektual yang dimiliki, digunakan, atau diperoleh dalam bisnis perusahaan serta review terhadap pengelolaan, pemeliharaan, pemanfaatan, dan penegakan hukum HKI.

Menurut Leslie J. Lott $^{24}$ Pertimbangan waktu yang tepat bagi perusahaan melakukan audit kekayaan intelektual sebagai bagian dari evaluasi kegiatan bisnisnya adalah: a) Manajemen Baru Kekayaan Intelektual, b) Merger, Akuisisi, Joint Venture, c) Pengalihan atau Kepentingan Penugasan Kekayaan Intelektual, d) Program Perjanjian Lisensi (Perizinan), e) Perubahan Signifikan dalam Peraturan Perundangundangan, f) Transaksi Keuangan

\footnotetext{
24 Leslie J Lott, Taking Stock of an Intellectual Property Inventory: How to Conduct an Intellectual Property Audit, sumber: http://www.patenfla.com/article/ipaidut.htm. 1998, Lott\&Friedland, P.A., Miami, FL, tanpa halaman, diakses pada 14 November 2013
} 
yang Melibatkan Kekayaan

Intelektual, g) Launching produk atau jasa baru dalam bisnis.

Setiap audit kekayaan intelektual memfokus dirinya pada empat kajian utama ${ }^{25}$. Pertama, advokat / konsultan HKI atau personil intern perusahaan dalam melakukan auditing HKI perlu mengidentifikasi terlebih dahulu semua aset kekayaan intelektual yang dimiliki oleh perusahaan.

Kedua, advokat / konsultan HKI atau personil intern perusahaan mengidentifikasi setiap masalah yang ada sehubungan dengan kepemilikan hak kekayaan intelektual atau setiap kekeliruan dalam pemberlakuan kekayaan intelektual perusahaan. Sedangkan yang keempat, advokat/konsultan HKI atau personil intern perusahaan mesti mengidentifikasi aset kekayaan intelektual yang tidak dilindungi hukum HKI.
2. Mekanisme Pelaksanaan Audit HKI yang Bertujuan Untuk Mencegah Terjadinya Risiko Kerugian Bisnis

Ruang lingkup audit kekayaan intelektual akan tergantung pada alasan mengapa perusahaan menginginkan untuk melakukan audit. Apabila audit kekayaan intelektual dilakukan sebagai bagian dari perumusan atau review terhadap keseluruhan strategi bisnis dalam pengelolaan aset, maka masingmasing modul di dibawah ini direkomendasikan. Singkatnya, tiga tahap audit kekayaan Intelektual sebagai berikut berikut:

25 Nancy Baum Delain, The Intellectual Porperty Audit, Les Nouvelles, Vol. 38 No. 4,193-200, Dec. 2003, tanpa halaman. 


\section{Tabel}

\section{Audit Hak Kekayaan Intelektual}

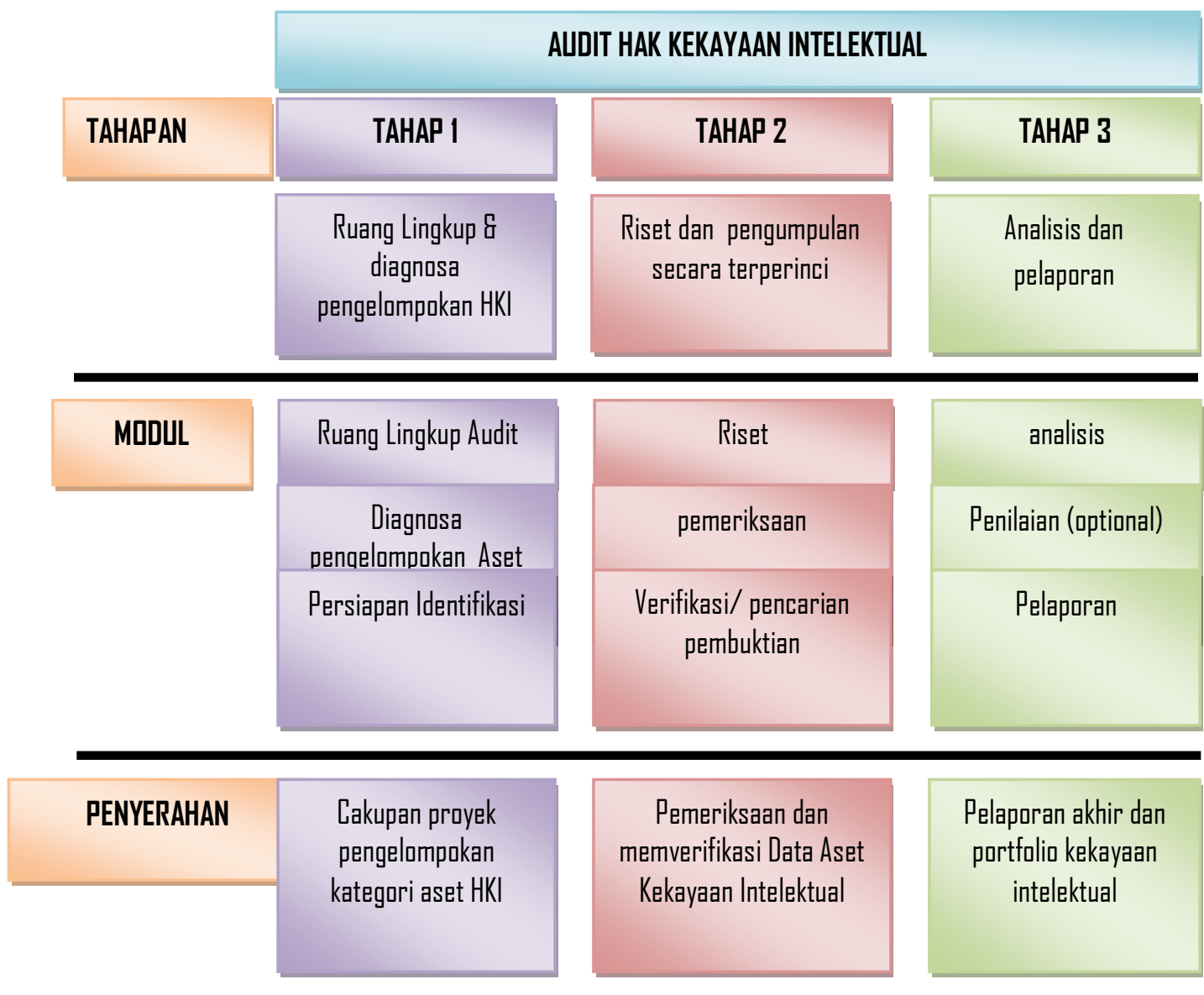

Sumber: Sharyn Ch'ang \& Marina

Yastreboff, Intellectual Property Auditing: A Road to Riches, Journal of Research and Practice in Information Technology, Vol. 35 No. 3, Agustus 2003, hlm. 174

Pelaksanaan audit HKI berbasis risiko secara lebih menyeluruh dilaksanakan dengan melalui beberapa tahap, sebagaimana digambarkan dibawah ini.
Step 1: Menginventarisasi Hak Kekayaan Intelektual perusahaan

Tim auditor kekayaan intelektual biasanya dimulai pekerjaannya dengan membuat daftar rinci tentang modifikasi untuk jenis dan ukuran bisnis perusahaan, hukum HKI yang relevan dari setiap negara yang relevan, tujuan-tujuan 
yang diinginkan, dan hasil-hasil yang diinginkan dari pekerjaan audit ${ }^{26}$.

Sebagaimana keumuman struktur perusahaan terdapat beberapa divisi, sehingga setiap divisi akan melakukan dan menghasilkan material-material bisnis yang berkaitan dengan hak kekayaan intelektual. Sehingga bisa diinventarisasi hak kekayaan intelektual berdasarkan: a) Divisi Sales dan Marketing, b) Divisi Personalia (Human Resources Department), c) Divisi Legal (Kontrak dan Administratif), d) Divisi Graphis, produksi dan pelayanan informasi, e) Divisi Research, Engineering and Development (Penelitian dan Pengembangan), f) Semua Departemen atau Divisi Perusahaan Step 2: Mengkategorisasikan HKI berdasarkan kelas masing-masing Tentukan setiap bagian HKI milik perusahaan kepada salah satu dari empat kategori dibawah ini: a) Produk: setiap produk yang dipasarkan. b) Proyek: setiap proyek yang masih dalam tahap konseptual. c) Area fungsional: setiap kekayaan

The World Intellectual Property
Organisation, Module 10: IP Audit, (World
Intellectual Property Organisation:
WIPO), tanpa halaman.

intelektual yang berkaitan dengan aktifitas perusahaan yang berdampak pada lebih dari satu produk atau proyek. d) Lain : setiap aset yang tidak sesuai dengan semua kategori diatas.

Step 3 :Mengaudit kontrak / perjanjian yang berbeda

Bagian penting dari audit HKI adalah mengidentifikasi dan menilai kecukupan ketentuan yang relevan dalam semua perjanjian yang menyangkut perlindungan HKI. Bentuk-bentuk kontrak/perjanjian tersebut sebagai berikut ${ }^{27}$ : a) Perjanjian Lisensi, b) Perjanjian kerja atau perjanjian tugas dalam kedinasan, c) Perjanjian Joint Venture dan Perjanjian Kolaborasi, d) Perjanjian pemberian dana bantuan Penelitian dan Pengembangan, e) Perjanjian Alih teknologi, atau pengetahuan (know how) atau perjanjian perbantuan teknik (technical assistance agreements), f) Perjanjian Desain dan pengembangan, g). Perjanjian penyelesaian sengketa, h) perjanjian waralaba, i) perjanjian royalti, j) perjanjian pemasaran, k) Perjanjian distribusi / Distributor, 1) Perjanjian

${ }^{27}$ IP Audit-WIPO, tanpa halaman. 
perwakilan penjualan, m) perjanjian Konsultasi atau manajemen, n) perjanjian outsourcing,o) perjanjian Pemeliharaan dan perbaikan, p) Perjanjian Pengalihan material, q) perjanjian pemrograman, r) perjanjian kode escrow (sehubungan dengan perangkat lunak).

Step 4: Mendeteksi pelanggaran hak kekayaan intelektual

Mengkaji ulang segala kebijakan perusahaan sehubungan dengan penegakan hukum hak kekayaan intelektual sebagai sistem sendiri atau untuk menghormati hak hukum pihak lain. Jika aset HKI tersebut dimiliki oleh perusahaan maka suatu audit dapat memberikan informasi mengenai apakah aset yang dimaksud dilanggar oleh pihak lain.

Step 5: Menyusun Laporan Audit HKI

Langkah selanjutnya adalah mempersiapkan penulisan deskripsi dari beragam aset HKI yang telah di audit, dengan memberikan rincian teknis tambahan dan spesifik dari setiap aset tersebut, dengan menangkap kembali proses dan kontribusi dari setiap aset kekayaan intelektual dengan rincian signifikan.
Setelah dideskripsikan aset tersebut, kemudian mempersiapkan laporan tertulis untuk setiap aset HKI dengan review memakai pendekatan, a) kajian hukum. Menilai lanjutan dari keberlakuan dan pengakuan hukum hak kekayaan intelektual untuk setiap aset HKI yang ditemukan dalam auditing , di yuridiksi mana HKI tersebut di daftarkan atau diajukannya aplikasi permohonan. b) kajian teknis. Tentukan apakah aset tersebut masih relevan dengan proses kegiatan bisnis perusahaan atau operasi perusahaan. c) kajian komersial. Menilai kontribusi kompetitif aset (misalnya apakah hilangnya aset akan merugikan perusahaan atau membantu pesaingnya).

\section{SIMPULAN}

Berdasarkan pembahasan yang telah dikemukan tersebut, diperoleh simpulan sebagai berikut:

1. Audit HKI memiliki Peran dan Kedudukan strategis sebagai sarana antisipasi dan/atau minimalisasi risiko kerugian bisnis. Tujuan dari dilakukannya audit HKI secara integratif memperkuat pengendalian 
internal perusahaan yang lebih baik didalam penggunaan aset Hak Kekayaan Intelektual untuk menghasilkan keuntungan nilai dan ekonomi serta mendorong pengelolaan risiko perusahaan yang lebih baik dibidang perlindungan Hak Kekayaan Intelektual. Audit HKI berbasis risiko lebih menekankan pada bagaimana posisi perusahaan agar tetap waspada pada persaingan bisnis agar tidak terjerumus pada tindakantindakan pelanggaran hukum hak kekayaan intelektual ataupun dengan adanya risiko tersebut mampu mendeteksi potensi keuntungan nilai dan ekonomi dari aset HKI yang dimiliki perusahaan, misalnya semestinya perusahaan mendapatkan royalti dari lisensi HKI, akibat dari tidak terkelolanya atau diabaikannya peranan HKI bagi perusahaan.

2. Langkah-langkah dalam melakukan implementasi dan audit HKI untuk mengantisipasi risiko bisnis adalah dengan cara, pertama, tim auditor yang terdiri advokat / konsultan HKI atau personil intern perusahaan perlu mengidentifikasi terlebih dahulu semua aset kekayaan intelektual yang dimiliki oleh perusahaan. Kedua, tim auditor mengidentifikasi setiap masalah yang ada sehubungan dengan kepemilikan hak kekayaan intelektual atau setiap kekeliruan dalam pemberlakuan kekayaan intelektual perusahaan. ketiga, tim auditor mesti mengidentifikasi aset kekayaan intelektual perusahaan yang tidak dilindungi hukum HKI. Pelaksanaan audit HKI berbasis risiko dapat dilakukan secara periodik tergantung dari kebijakannya, namun dalam situasi-situasi dibawah ini, perusahaan mesti melakukan auditing HKI. siatuasi tersebut meliputi: a) sebelum berdirinya perusahaan baru, dimana perusahaan membutuhkan kesadaran terhadap aset tidak berwujud yang dimilikinya atau mungkin dibutuhkan untuk dilindungi. b) ketika sebuah bisnis didirikan yang mempertimbangkan pelaksanaan kebijakan baru, standar, atau 
prosedur baru yang berkaitan dengan kekayaan intelektual.c) ketika sebuah bisnis mempertimbangkan untuk melakukakan pendekatan baru pemasaran, atau berencana untuk mere-organisasi perusahaan melalui merger, likuidasi, joint venture, dan kolaborasi usaha, d) ketika seorang personil perusahaan bertanggung jawab pada pengelolaan kekayaan intelektual.

\section{A. SARAN}

Berkaitan dengan hasil penelitian dan pembahasan yang telah diuraikan, maka penulis menyarankan:

1. Dibuatnya tools yang lebih komperehsif berkenan dengan audit HKI berbasis risiko, karena Eksistensi audit HKI pada mayoritas perusahaan di Indonesia belum menjadi bagian signifikan yang terintegrasikan dalam struktur organisasi perusahaan, namun masih menjadi material terkecil dari internal audit secara keseluruhan, sehingga hal demikian memberikan indikasi bahwa audit HKI masih belum menjadi salah satu strategi bisnis perusahaan dalam mengantisipasi perusahaan menghadapi beragam risiko kerugian bisnis ataupun dalam peningkatan komoditas keuntungan nilai dan ekonomi. Padahal sebagaimana dijelaskan dalam penulisan karya tesis ini, penulis berpandangan bahwa audit HKI berbasis risiko merupakan bagian penting dalam tata kelola perusahaan khususnya dalam mengamankan dan menginventarisir aset HKI yang tidak terlepaskan dari perspektif ekonomi bahwa aset HKI yang lebih memberikan manfaat nilai dan ekonomi bagi perusahaan daripada aset berwujud lainnya.

2. Materi keilmuan Hukum Hak Kekayaan Intelektual, saat ini, telah menjadi bagian integral pada program studi Fakultas Ilmu Hukum di beberapa Universitas di Indonesia, namun adanya 
pemahaman sebagian pakar ahli hukum mengenai materi keilmuan Audit HKI dianggap bukanlah bagian dari kajian ilmu hukum sudah semestinya dirubah mindset tersebut, sebab materi audit HKI merupakan metode keilmuan praktis dalam mengaplikasikan materi Hukum Hak Kekayaan Intelektual. oleh karena itu, penulis menyarankan agar materi audit HKI bisa menjadi satu ilmu praktis seperti halnya materi-materi hukum bisnis lainnya, yang diajarkan khusus disetiap Fakultas Magister Ilmu Hukum program studi Hukum Hak Kekayaan Intelektual dibeberapa Universitas.

\section{DAFTAR PUSTAKA}

Adam I. Indrawijaya, Perilaku Organisasi, cetakan VI, (Jakarta: Sinar Baru Algensindo, 2000)

Annual Report Laporan Tahuan 2011 Direktorat Jenderal Hak Kekayaan Intelektual Kementerian Hukum dan
HAM RI, (Jakarta; Ditjen HKI, 2011)

Ardeno Kurniawan, Audit Internal Nilai Tambah Bagi Organisasi, (Yogyakarta: BPFEUGM, 2012)

Budi Santoso, Hukum Hak Cipta, Catatan Perkuliahan pada Magister Ilmu Hukum UniversitasDiponegoro Semarang, 2013

C.S.T. Kansil, Pengantar Ilmu Hukum dan Tata Hukum Indonesia, (Jakarta: Balai Pustaka, 1989).

Candra Irawan, Politik Hukum Hak Kekayaan Intelektual di Indonesia, (Bandung: Mandar Maju, 2011)

Justin Hughes, The Philosophy of Intellectual Property, (Washington: Georgetown Law Journal, 1988),

Krisnani Setyowati, Efridani Lubis dkk., Hak kekayaan Intelektual dan Tantangan

Implementasinya $d i$ Perguruan Tinggi, (Bogor: Kantor HKIIPB, 2005)

Leslie J Lott, Taking Stock of an Intellectual Property Inventory: How to Conduct an Intellectual Property Audit, sumber: http://www.patenfla.com /article/ipaidut.htm. 1998, Lott\&Friedland, P.A., Miami, FL, tanpa halaman, diakses pada 14 November 2013

Manahan Nasution, Sekilas tentang Internal Auditor, 
makalah,( Sumatra: FE

USU, 2003)

Nancy Baum Delain, The Intellectual

Porperty Audit, Les

Nouvelles, Vol. 38 No.

4,193-200, Dec. 2003,

Nyoman Serikat Putra Jaya, Hukum

dan Hukum Pidana

diBidang Ekonomi,

(Semarang: Badan

Penerbit Universitas

Diponegoro, 2012)

Ontoeng Soerapati, Hukum

Kekayaan Intelektual dan Alih Teknologi, (Salatiga: Fakultas Hukum UKSW, 1999)

R. Soekardono, Hukum Dagang Indonesia: Jilid I, cet. ke-9, (Jakarta: Dian Rakyat, 1993),

Stacey \& Halpern, etc, Protecting your Company's Intellectual Property Through an IP Audit: a Guide for Small to MidSized Businessess, (USA: Execsense, Inc. 2012)

The World Intellectual Property Organisation, Module 10: IP Audit, (World Intellectual Property Organisation: WIPO),

William W Cochran, Intellectual Property Audits, Makalah tanpa tahun. 